THE LONDON JOURNAL, Vol. 44 No. 1, 2019, 1-10

EVENT REPORT

\title{
The Whitechapel History Fest: A Report of an Event Organized by the Survey of London
}

\author{
Peter Guillery (i) \\ Survey of London
}

'It was very much a community event, not for gentrifiers.' So said Charles Saumarez Smith in a response to a comment on his blogpost about Dan Cruickshank's 'bravura final talk' at the Whitechapel History Fest in the Idea Store Whitechapel on 27 October 20I8. Set it aside that in EI Dan Cruickshank was surely among the original gentrifiers, and thus someone to whom we owe the preservation of a good deal of historic fabric that few would now wish swept away. For the Survey of London the judgement felt like high praise indeed, a vindication of what the event had set out to achieve. This was a 'fest', not a conference, programmed to connect the work of the Survey of London with the initiatives and experiences of numerous others, to inform research and to reach new audiences (not excluding gentrifiers). Two large rooms on the first floor of the Idea Store, one normally used as a Dance Studio, hosted parallel sessions and were humming if not hopping across three days, ending up with standing room only. There were more than 200 attendees overall.

To take a few explanatory steps back, the Survey of London is a unique enterprise. It was begun in the I 890 s to identify and describe historic buildings and monuments with a broader purpose - set out by its founder, the architect and co-operativist C. R. Ashbee - to enlighten and educate the public. In the steps of John Ruskin and William Morris, Ashbee had a strong romantic socialist commitment to the advancement of equality through shared understandings of a common built environment. He established the Survey of London as a vehicle for public history, to mobilise resistance to the commodification of London's historic and everyday fabric. Initial projects were in East London. The Survey was supported by the London County Council, where its purposes knitted well with the dominant Progressive party's determination to raise historical consciousness as a counter to the interests of private property. The LCC's municipal political philosophy, and such there was, lay great emphasis on the historical origins of what we might now term the commons. ${ }^{2}$ The Survey built on this relationship, formalised in I9 Iо, and developed into a pioneering work of urban and architectural history. It continued to evolve in scope and methods under the LCC then the GLC, and under central government, latterly at 
English Heritage, and then since 2013 at the Bartlett School of Architecture in University College London. There are fifty-two volumes to date in the main series, and eighteen monographs on major sites. Each volume describes an area's-buildings past and present, their origins, significance and associations, and is illustrated with archive views, new photographs, and maps and measured drawings produced in-house. Acknowledged for scholarship and accessibility, the books have been consistently praised by reviewers in the mainstream press, academic journals and localhistory publications, and latterly through social media. All but the most recent volumes are accessible digitally through British History Online, where they are the second most consulted source after Ordnance Survey maps. The Survey has always been intentionally wide in its reach. Scholarly impact aside, its work has fed into the listing of buildings, broadcasting and journalism. It is widely used by bloggers, family historians, homeowners, architects, planners, estate agents, developers and campaigners against developers.

However, from its new perch within a university, the Survey risks estrangement from its public-history origins and ethos. Further, it has long been clear that technological developments, digitisation and the internet, were transforming the practice of history and the scope for public engagement. At English Heritage there was no access to funds whereby to exploit this potential. With assistance from its new Bartlett colleagues, the Survey addressed this in 2015 by securing a major Arts and Humanities Research Council grant to create a digital and participative approach to its research. ${ }^{3}$ Whitechapel was chosen to be the study area for this experiment, in large part because the place is undergoing immense change, making recording all the more vital, a recurrent motive in the Survey's programmes. It also happened to be a return to Ashbee's point of departure.

Work in Whitechapel reflects the Survey's public-history roots and cultivates anew connections outside academia. Research has been conducted and material accumulated through an interactive map-based website 'Survey of London - Histories of Whitechapel', 4 to which the public has been invited to contribute research, information, memories and images; oral history is an important aspect. Since September 2016 the website has attracted more than 600 collaborators (Figure I).

The Whitechapel History Fest was a programme of talks and discussions to mark the concluding phase of this AHRC-funded project. Few of the contributors or attendees were from academia. Architecture and its social implications were emphasised, while elements ranging from poetry readings to the premiere of a commissioned film on the history of Whitechapel's Bangladeshi restaurants were intended in part to widen the Survey's audience without disregard to the built environment.

The Fest and the Survey of London's Whitechapel project as a whole have set out to retrieve an aspect of Ashbee's founding ethos, that of the craft workshop, to widen the definition of who is responsible for authorship. We have deliberately blurred the boundaries between 'unofficial history' and 'official history', to use Raphael Samuel's terms, responding to his argument that 'history is not the prerogative of the historian', but is 'rather, a social form of knowledge; the work, in any given instance, of a thousand different hands.' 5

The Whitechapel History Fest kicked off on the Thursday evening with a lecture by Rachel Lichtenstein titled 'Avram Stencl: The Yiddish Poet of Whitechapel'. This 


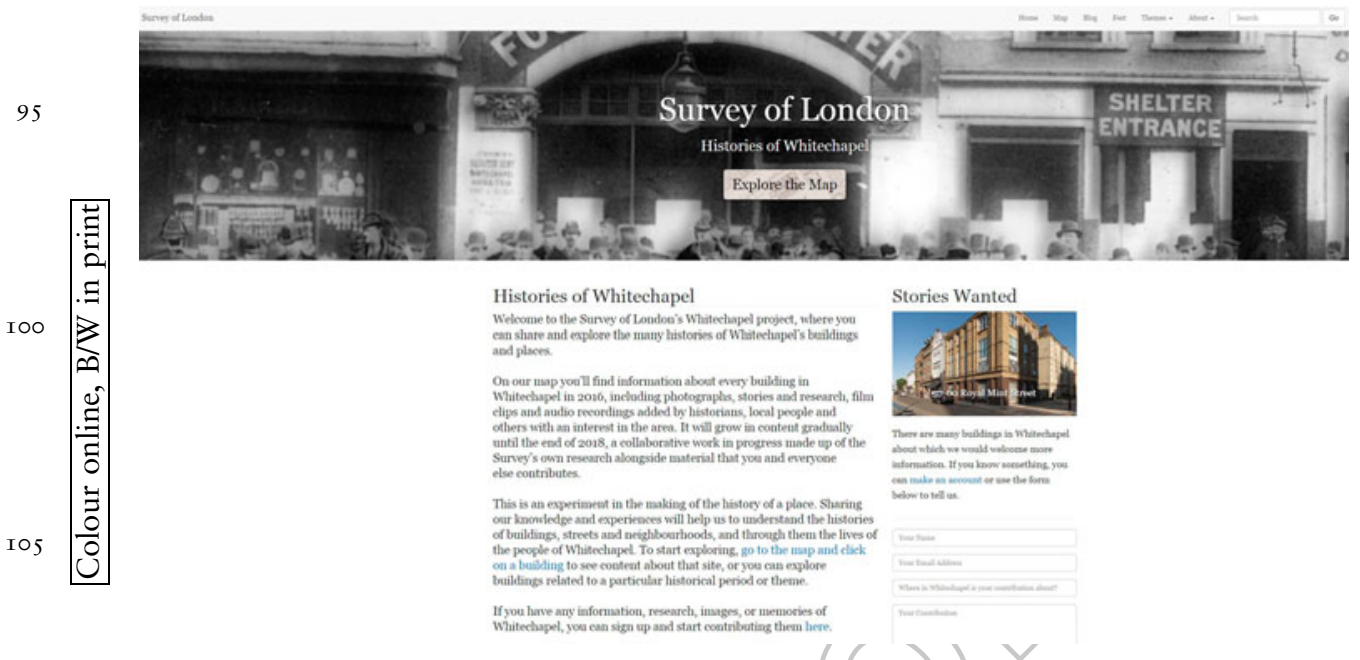

FIGURE 1 Survey of London - Histories of Whitechapel website homepage.

had its roots in Rachel's childhood memories and was suffused with personal admiration, also setting out clearly the complex life story of this singular but largely forgotten figure, once a Whitechapel fixture known for calling out koyfts a heft (buy a pamphlet). This was followed by poetry readings. These were by: Celeste, a teacher and performance artist who read several short works exploring time, place and identity in London; Chris Searle, who has written on local themes since publishing schoolkids poetry in Stepney Words in I971, and who read Isaac Rosenberg's 'Dead Man's Dump'; Stephen Watts, who has similarly long links to the locality that include collaborations with Iain Sinclair and Rachel Lichtenstein, he read his 'Brick Lane Mela Poem'; and finally Bernard Kops, age 9I with all the strength and chutzpah he attributes to his East End origins, who read his 'Whitechapel Library, Aldgate East' and more (Figure 2). There was a strong emotional energy to this occasion, not least because it brought together such a notable group of distinctive local voices.

At this point it ought to be mentioned that the Survey of London's in-depth study of Whitechapel and its Jewish history has benefitted from a scholarly collaboration with Dr Sharman Kadish and from numerous oral histories gathered from as far away as Israel. This harvest and the attractively interactive qualities of the Whitechapel project's website have led to a spin-off project, 'A Memory Map of the Jewish East End', which has secured its own funding through a substantial Bartlett grant. This is being curated by Rachel Lichtenstein in collaboration with Bartlett staff.

The format of the rest of the event over two days was parallel sessions, a series of talks in one room with discussions in another. The first day's talks highlighted aspects of the histories of some of the multiple communities to have inhabited Whitechapel. Sarah Milne of the Survey of London and a co-organiser spoke about Whitechapel's Deutsche Kolonie, the German migrants and their descendants in the area who numbered as many as 20,000 before First World War expulsions. She focussed on their connection with the huge and prosperous sugar-refining industry and 


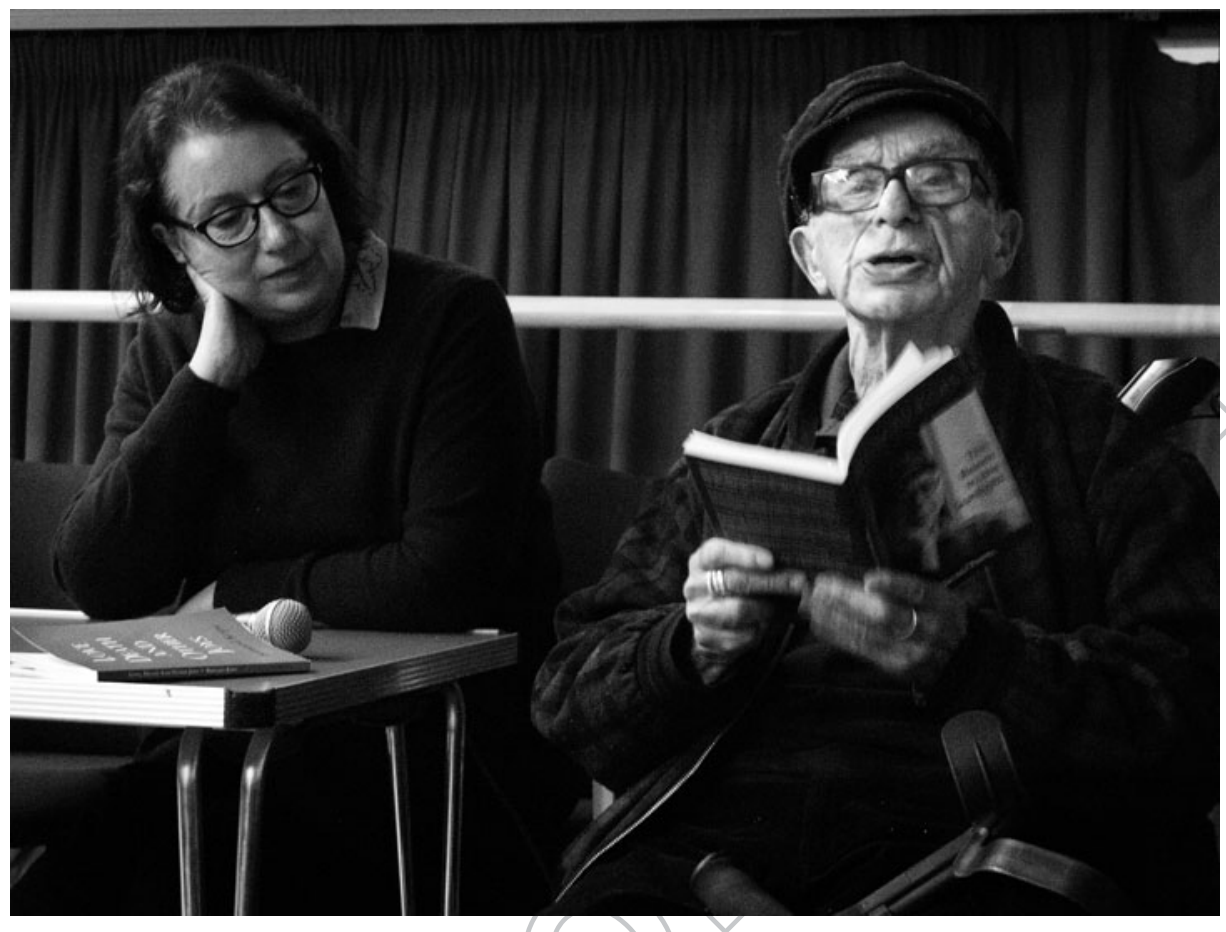

FIGURE 2 Bernard Kops reading his poem 'Whitechapel Library, Aldgate East', with Rachel Lichtenstein at the Whitechapel History Fest (Photograph courtesy of Ron McCormick (C).

looked at instances of everyday life in this forgotten milieu as retrieved from archival sources. Alan Dein followed with 'The Petticoat Lane Foxtrot', a lively jaunt from an accomplished broadcaster through Cockney-Jewish jazz of the I920s to I950s, punctuated by song extracts on subjects ranging from beigels to the Festival of Britain. The Dance Studio audience was almost on its feet. Next, Julie Begum, Chair of the Swadhinata Trust, spoke about Bangla Town and the Bengali East End addressing origins and moving on to settlement and memorialisation. Hudda Khaireh spoke to the title 'Hido Raac: place-making and demarcating', presenting a 'walking odyssey' exploration of the sites and histories of the Somali community in East London. She addressed how communities and geographies are formed and contemplated the ideologies of 'mapping'. Chris Searle then combined with Ron McCormick, a long-time partnership forged in I970s Whitechapel, with a talk titled 'Whitechapel Boys' about those times and their re-appraisal of Isaac Rosenberg's poetry that reflects on Whitechapel's history across the century since Rosenberg's death (Figure 3). ${ }^{6}$ The last talk of the day was by the Gentle Author, the renowned local writer of the Spitalfields Life blog, on 'East End Vernacular: artists who painted the East End streets in the twentieth century', showing dozens of under-appreciated paintings, a subject he covered in a book with a similar title published in 2017.

The first day's parallel discussion sessions were intended to set up something of a dialogue with these talks. It was of course impossible to attend everything, but the 


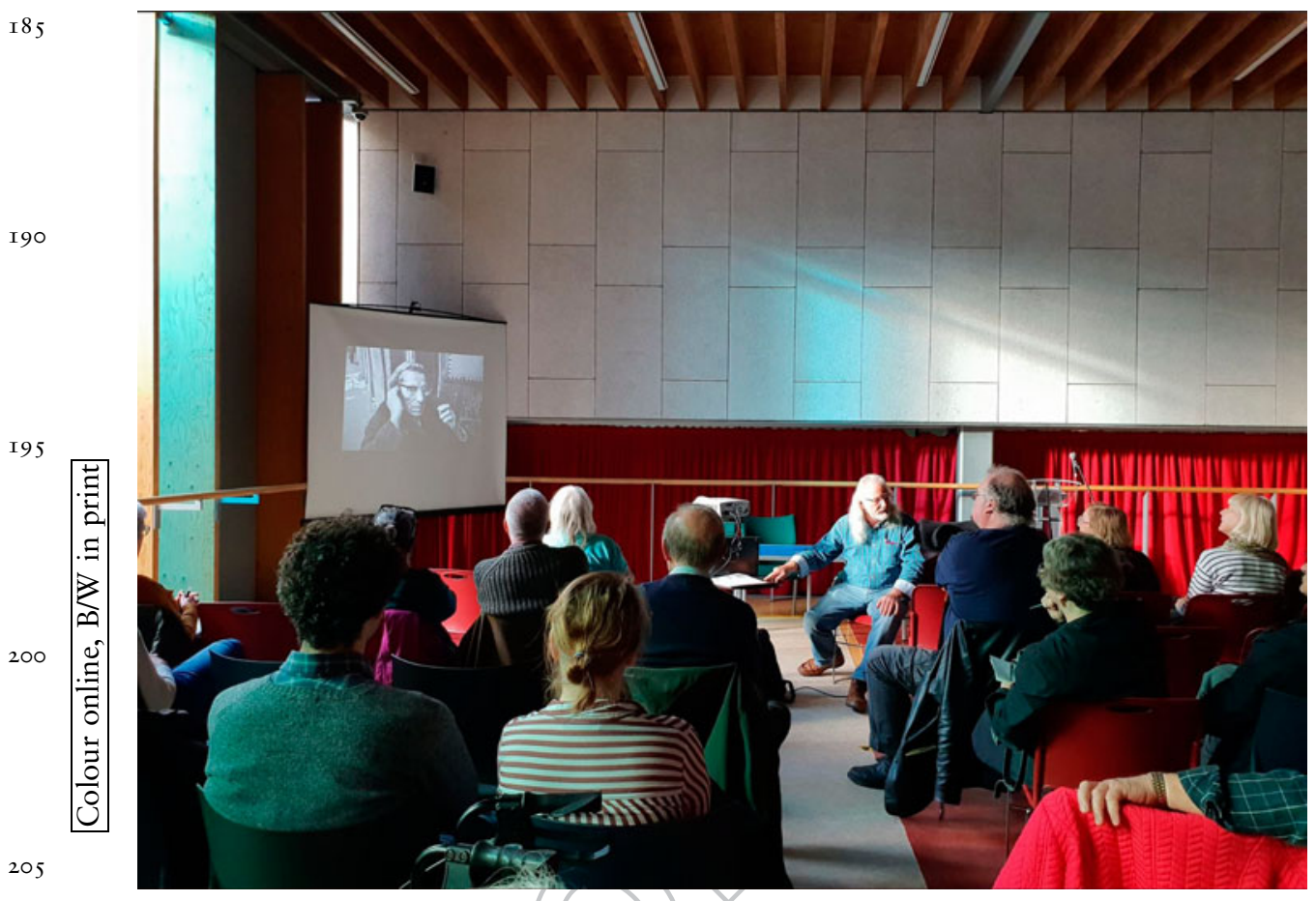

FIGURE 3 Ron McCormick speaking about the 1970s in Whitechapel (photograph by Shahed Saleem).

programming allowed for complementary subjects not to clash. A session on 'Mapping and Place' was chaired by Duncan Smith, of UCL's Centre for Advanced Spatial Analysis and Co-Investigator for the Survey's Whitechapel grant, bringing together Seif El Rashidi, project manager for Layers of London, a participative mapbased website based at the Institute of Historical Research and launched in 20I8, Shlomit Flint, an architect also based at CASA who has carried out detailed demographic research in Whitechapel and whose work centres on the impacts of immigration, Duncan Hay, who has expertise on psychogeography and English literature and who was responsible for the design and functioning of the Survey of London's Whitechapel website, and Laura Vaughan, Director of the Space Syntax Laboratory at the Bartlett. The panel talked about the-ideas of 'ownership' of place, and the-issues around the mutability of meaning in maps and negotiation of them by different users.

A session on sailors and settlement brought together diverse understandings of different periods of history connected by an interest in the southern parts of the parish of Whitechapel, where proximity to the Thames and the port has brought numerous seafaring people across centuries. Kinsi Abdulleh, founder of NUMBI Arts, spoke about the social spaces of the Somali sailor population near Wellclose Square. In particular she drew attention to the importance of community archiving as a way of connecting young people with histories of place in a meaningful and personal way. Derek Morris, the author of numerous books about East London's 
eighteenth-century social history, concentrated on that period, and Tamsin Bookey, Heritage Manager at Tower Hamlets Local History Library \& Archives, pointed to the value of the Edith Ramsay papers for information about settlement in this area after the Second World War in the last active years of the upriver port.

Community is of course a problematic word. It was deliberately paired with another difficult word for a panel discussion titled 'Heritage and Community'. This was chaired by Shahed Saleem, a research fellow with the Survey's project and a co-organiser of the event, in conversation with Emily Gee, Historic England's London Planning Director, Hudda Khaireh, as above, Will Palin, the Director of Conservation at the Old Royal Naval College, Greenwich, and a founder of the East End Preservation Society, and Howard Spencer, who is responsible for London's blue plaques scheme for English Heritage. Position statements alone were enough to support the point made from the floor that there is more than one community in Whitechapel. Equally, there is no single heritage. A fruitful discussion ensued, lit-up in particular by Tamsin Bookey's mention of developer 'heritagewashing' (lip-service concessions). Whose side are we on? As with several of the discussions, things were hampered by shortage of time.

Three short accounts of histories from archives followed, by Malcolm Barr-Hamilton, long the Archivist for the London Borough of Tower Hamlets, Dor Duncan, an archivist and artist at Whitechapel Gallery, and Jamil Sherif, Chair of the East London Mosque Archives Steering Group. To complete this strand there were four short talks. David Charnick, an experienced guide in the City and Tower Hamlets, spoke about George Holland's work to alleviate distress caused by poverty in late nineteenth-century Whitechapel. Jil Cove reflected on fifty years living in Whitechapel, in particular on life working at the London Hospital in the I960s. Rebecca Preston, based at Royal Holloway and the Institute of Historical Research, and also now a collaborator with the Survey, spoke about investigations into the history of the Co-operative Wholesale Society, headquartered on Leman Street and Prescot Street from I88I. Finally, Carole Zeidman, until recently a historian and guide at Wilton's Music Hall, spoke about that unique place.

The Fest's final day was given a vigorous lift-off by Ajmal Masroor, locally born and now an imam, broadcaster and politician (Figure 4). He spoke powerfully about being of Bangladeshi origin and growing up in the area in the I970s amid regular and sometimes violent racist abuse, experiences he precisely rooted in place. This was turned to positivity, not least through mention of a recent and redemptive encounter with a former antagonist. A raw but rewarding question-and-answer session followed. Ensuing talks represented a dramatic change of gear. A sequence of presentations by Survey of London historians traced aspects of Whitechapel's architectural history in more traditional Survey modes. The present author spoke about 'survivals and traces' of pre-Victorian buildings in Whitechapel. There are some well-known major early survivals, the Whitechapel Bell Foundry for example, but much of the extant evidence for older Whitechapel is more fragmentary and trace-like, from the site of the parish church (the 'white chapel') to a last remnant on Davenant Street of the once ubiquitous sugarhouses. Amy Smith spoke about the expansion and remodelling of the London Hospital in the years around 1900, extolling the accomplishments of Rowland Plumbe, the architect 
who oversaw transformative modernisation of one of London's great hospitals. Aileen Reid, a co-organiser, tracked connections in the late-Victorian origins of Toynbee Hall, the Whitechapel Gallery and the Survey of London, through the Christian Socialist career of Canon Samuel and Henrietta Barnett to Ashbee, describing the settlement movement and aspirations for art as a means to bettering working-class lives. Then Shahed Saleem spoke about the building in the mid-I98os of the East London Mosque and the Jagonari Centre, two important community projects at a watershed moment for racial, religious, gender and community relations in Whitechapel. ${ }^{7}$

In parallel, there were more discussion and short-talk sessions. Celeste, Gary Hutton and Danny McLaughlin, all active through local social media and with diverse local roots, were in conversation with Aileen Reid about sharing local history (Figure 5). All three spoke about the importance of online sharing as a social communitarian experience, as a way to begin conversations about place, and to link these conversations to wider social and cultural issues - identity, selfexpression, gentrification, the importance of education as a route out of poverty; these were themes that emerged. Sigrid Werner, another local historian, spoke further about Whitechapel's Germans and their connections with the sugar industry, followed by Andrew Byrne who looked into the architecture of the remarkably tall sugarhouses, a subject he had stumbled onto in building a scale model of London as it was in 1840 - in wood, not software. David Rosenberg, a historian and author 


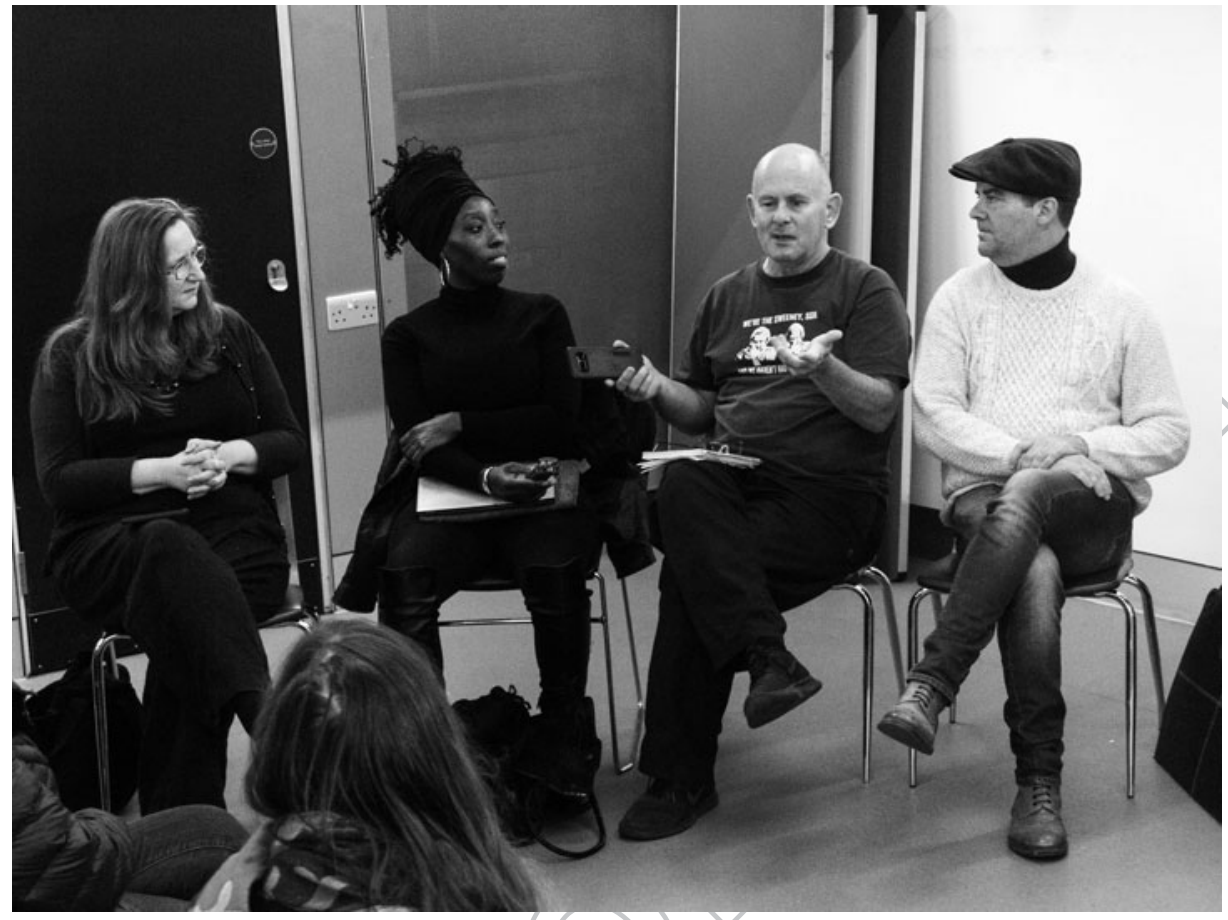

FIGURE 5 Aileen Reid, Celeste, Danny McLaughlin and Gary Hutton discussing the sharing of local history through social media at the Whitechapel History Fest (Photograph courtesy of Ron McCormick (C).

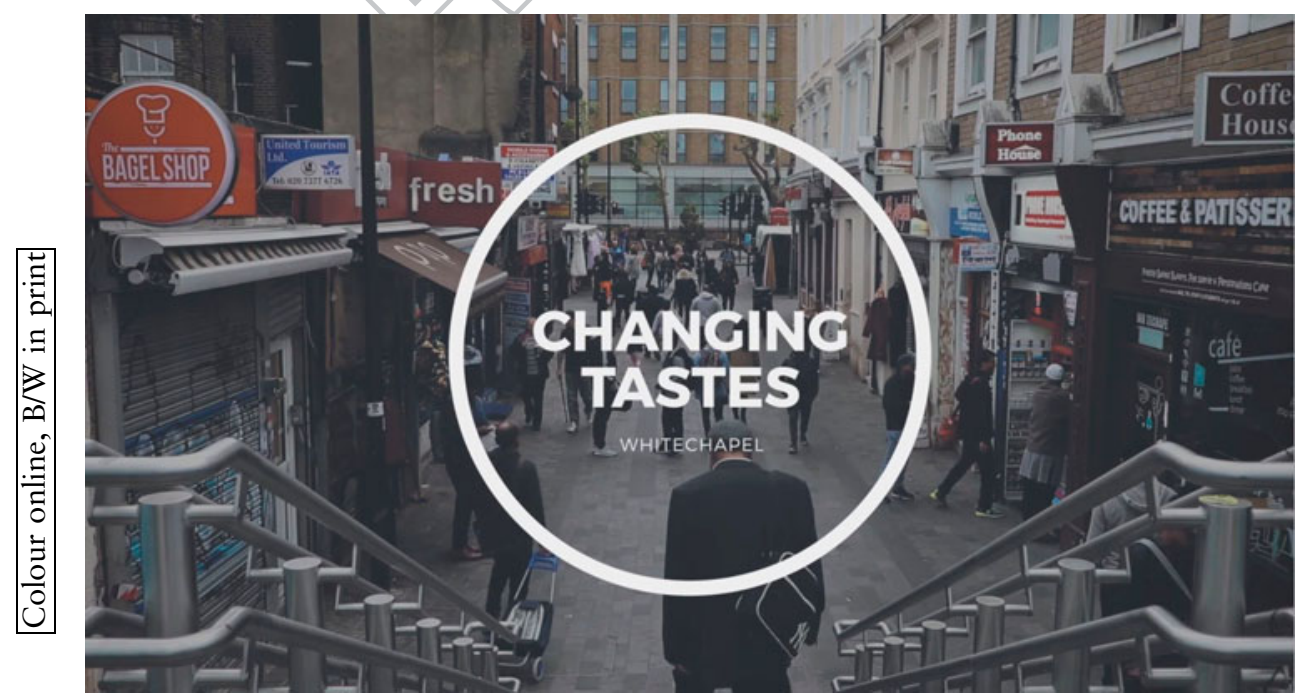

FIGURE 6 Still from 'Changing Tastes: Whitechapel's south Asian restaurants', film by Nurull Islam and Rehan Jamil premiered at the Whitechapel History Fest. 
FIGURE 7 Former sugar refinery, converted to tea warehouse, Dock Street, Whitechapel, in the early 1970 (photograph by Dan Cruickshank).

on London's radical history, spoke about 'East End Rebels I 88 os to I930s'. After that came the premiere screening of a specially commissioned short film, 'Changing Tastes: Whitechapel's south Asian restaurants', by Nurull Islam, Centre Director for the Mile End Community Project, and Rehan Jamil, a documentary photographer. This comprised a series of interviews and site studies tracing the history of local restaurants across recent decades (Figure 6). There was also a wrapping-up open discussion of the Survey of London's Histories of Whitechapel project that addressed, among other things, overlaps with the Layers of London, the longevity of digital data, and the Survey's future publication plans in a changing landscape.

Everyone came together for Dan Cruickshank's finale, which featured his own evocative photographs from the early I970s of some remarkable and since- 
demolished buildings in Whitechapel and Spitalfields (Figure 7). He accounted for the establishment of the Spitalfields Trust later in that decade and traced subsequent preservation projects by the Trust in Whitechapel, from the former Buck's Row (Durward Street) Board School, to London Hospital Estate houses of c.I8 Io on Turner Street and Varden Street.

In a report in this journal of a very different event hosted by the Survey of London in 2010 , an international gathering of those involved in recording major European and North American cities, Andrew Saint and the present author concluded that 'Whatever new initiatives may arise, and they will no doubt be web-based if not community- or volunteer-based, coordination, maintenance of standards and dissemination loom as great challenges. ${ }^{8}$ Much water has flowed under the bridge since then, but those challenges are still with us.

Even so, it was gratifying that a booklet produced for the occasion was spotted days after the event in the hands of a guide showing students from the University of Oregon round Whitechapel. The Survey of London gratefully acknowledges the staff of the Idea Store Whitechapel for hosting and coping with this event. We were also hugely helped by and thankful for administrative support from Tanha Quadi, Nishat Alam and Zarin Begum.

\section{ORCID}

Peter Guillery (D) http://orcid.org/o000-0002-8324-6027

\section{Notes}

I https://charlessaumarezsmith.com/2018/10/2 $7 /$ whitechapel-2/.

2 K. Ito, 'Municipalization of memorials: progressive politics and the commemoration schemes of the London county council, I889-1907', The London Journal, 42:3 (2017), 273-90.

3 Arts and Humanities Research Council grant reference $\mathrm{AH} / \mathrm{Noo}$ 146X/I.

4 https://surveyoflondon.org.

5 R. Samuel, Theatres of Memory, Volume 1: Past and Present in Contemporary Culture (Verso: London, I994), 8.

6 C. Searle and R. McCormick, Whitechapel Boy: a Reading of the Poetry of Isaac Rosenberg (Blurb, 20I8).

7 Shahed Saleem, The British Mosque: an Architectural and Social History (Swindon: Historic England, 20I8).

8 A. Saint and P. Guillery, 'Recording the fabric of great cities: report of an international meeting organized by the Survey of London and sponsored by English heritage', The London Journal, 36:3 (20II), 269-74. 